\section{Pathophysiology of Haemostasis and Thrombosis}

\title{
Thromboembolic Diseases in Neonates and Children
}

\author{
Ulrike Nowak-Göttl, Christine Duering, Beate Kempf-Bielack, \\ Ronald Sträter
}

Paediatric Haematology/Oncology Univ. children`s hospital Münster, Germany

\section{Key Words}

Thrombosis · Thrombophilia $\cdot$ Children

\begin{abstract}
Acquired and inherited prothrombotic risk factors increase the risk of thrombosis in neonates, infants and children. After suffering thrombosis white paediatric patients should be screened for common gene mutations, i.e. the factor V G1691A, factor II G20210A and MTHFR C677T genotypes, rare inherited prothrombotic risk factors, i.e. deficiencies of protein C, protein $\mathrm{S}$, and antithrombin, plasminogen, probably inherited risk factors, i.e. fibrinogen, factor VIIIC, factor XII, new candidates, i.e. elevation of lipoprotein (a), and fasting homocysteine concentrations (3 - 6 months after thrombotic onset). Data interpretation is based on age-dependent reference ranges or the identification of causative gene mutations/polymorphisms with respect to individual ethnic backgrounds.
\end{abstract}

Copyright @ 2004 S. Karger AG, Basel

\section{KARGER}

Fax +4161306 1234 E-Mail: karger@karger.ch www.karger.com
C 2004 S. Karger AG, Basel 1424-8832/04/0336-0269\$21.0/0

Accessible online at: www.krager.com/pht

\section{Introduction}

Venous and arterial thrombosis are rare diseases being increasingly diagnosed and recognised also in infancy and childhood. Due to the special properties of the haemostatic system during infancy and childhood, symptomatic thrombotic manifestation occurs in $0.07 / 10,000$ children, 5.3/10,000 admissions of children, and 2.4/1000 admissions of newborns to intensive care units. Within the entire childhood population, possibly due to the lower concentrations of antithrombin, heparin cofactor II and protein C along with a reduced fibrinolytic capacity neonates are at a greater risk of thromboembolic complications than older children. The incidence of vascular accidents decreases significantly after the first year of life, with a second peak during puberty and adolescence again associated with a reduced fibrinolytic activity [1].

Thrombus formation and thrombus growth are the result of local coagulation activation combined with a disturbance in the balance between coagulation and fibrinolysis, leading to a prothrombotic state. Numerous clinical and environmental conditions (Table 1), such as peripartal asphyxia, neonatal infections, foetal diabetes, the use of central lines, trauma or surgery, dehydration, malignant diseases, renal diseases, autoimmune diseases, or the intake of oral contraceptives in adolescent girls resulted in elevated thrombin generation with subsequent thrombus formation in infancy and childhood [2-31].

Ulrike Nowak-Göttl

Univ. Children Hospital, Paediatric Haematology and Oncology

Albert-Schweitzer-Str. 33

D-48149 Münster, Germany

Tel: 0251834 7936/7744; Fax: 0251834 7828; E-mail: leagottl@uni-muenster.de 
Table 1. Acquired risk factors for paediatric thromboembolism [2-31]

\begin{tabular}{ll}
\hline Perinatal Diseases & Birth asphyxia \\
& Respiratory distress syndrome \\
Infants of diabetic mothers & Neonatal Infections \\
& Necrotizing entercolitis \\
& Dehydration \\
& Congenital nephrotic syndrome \\
& Polycytaemia \\
& Central Lines \\
& Operations \\
Medical Interventions & Renal transplantation \\
& Immobilisation \\
& Plaster Casts \\
& Extracorporeal membrane \\
& oxygenation \\
& Trauma \\
Acute Diseases & Sepsis \\
& Dehydration \\
& Acute Rheumatic Diseases \\
& Nephrotic syndrome \\
& Acute Lymphoblastic Leukemia \\
& Malignancies \\
& Renal Diseases \\
Cardiac Malformations \\
Chronic Diseases & Chronic Rheumatic Diseases \\
& E. coli asparaginase \\
& Prednisone \\
& Coagulation factor concentrates \\
& Heparins \\
Antifibrinolytic agents \\
Oral contraceptives \\
\hline
\end{tabular}

Various genetic prothrombotic defects (Table 2), particularly those affecting the physiological anticoagulant systems, i.e. antithrombin-, protein C-, and protein S-deficiency, the mutation of coagulation factor V (G1691A), and the factor II variant (G20210A) have been well established as risk factors of thrombotic events [32,33]. In addition, metabolic diseases such as homozygous homocystinuria, and moderate hyperhomocysteinemia due to the homozygous methylenetetrahydrofolate reductase (MTHFR) polymorphism C677T have been described, as well as increased concentrations of lipoprotein (a), which have been recently shown to significantly enhance the risk for thromboembolic arterial and venous thrombosis in paediatric and adult patients [32-37]. Since the discovery of activated protein C resistance as a highly prevalent hereditary risk factor of thromboembolism, evidence has been accumulating that thrombophilia is a multifactorial disorder [38]. The association of multiple haemostatic prothrombotic defects or the combination of established prothrombotic risk factors with acquired environmental or clinical conditions greatly increases the risk of thrombosis not only in adults but also in infants and children (Level II) [36-41].
Table 2. Inherited prothrombotic risk factors.

\begin{tabular}{ll}
\hline Common, & $\begin{array}{l}\text { Factor V G1691A gene mutation } \\
\text { Factor II G20210A gene mutation } \\
\text { Increased concentrations of } \\
\text { Apolipoprotein (a) } \\
\text { Homozygous C677T polymorphism } \\
\text { in the methylenetetrahydrofolate } \\
\text { reductase gene }\end{array}$ \\
Protein C-deficiency \\
Protein S-deficiency \\
Antithrombin-deficiency \\
Heparin cofactor II-deficiency \\
Increased homocysteine \\
concentrations > 10 mol/I[79] \\
Dysfibrinogenemia \\
Plasminogenemia \\
Homozygous homocystinuria \\
Increased levels of factor VIIIC, IX, \\
or fibrinogen \\
Probably inherited
\end{tabular}

\section{Thrombotic Locations in Paediatric Patients}

The most common sites of thrombus formation in neonates are the renal veins, vena caval occlusion, and peripartal thromboembolic stroke [2-7,23,24,42,43]. In addition, high rates of catheter-related thrombosis in neonates, infants and children have been reported [2-10,13,19]. Central venous lines lead to thrombus formation and thrombus growth near the catheter implantation site, especially when prothrombotic risk factors are involved. Further locations of childhood thromboembolism reported are cerebral venous thrombosis, portal and mesenteric vein thrombosis $[46,47]$, while arterial vascular occlusions have been reported mainly as ischaemic stroke $[27,35,42,43]$, and, catheterrelated thrombosis in the aorta, the femoral artery and the subclavian artery respectively.

Purpura fulminans is a life-threatening event characterised histologically by microvascular thrombosis in the dermis followed by perivascular haemorrhage. Haemorrhagic necrosis of the adrenal glands (WaterhouseFriderichsen syndrome), renal cortical necrosis may also occur. Clinically, progressive purpuric skin lesions and diffuse oozing from skin puncture sites are observed, often within hours after birth. The lesions are initially red and flat, quickly become indurated and necrotic, and may result in gangrene. The known underlying causes of purpura fulminans are disseminated intravascular coagulation (DIC), for example in response to bacterial septicaemia, i.e. for example B ß-haemolytic streptococcal disease, Neisseria meningitidis or streptococcus pneumoniae. In addition, in 
neonates congenital absence of protein $\mathrm{C}$ or protein $\mathrm{S}$, or the presence of homozygous or heterozygous factor V G1691A mutation have been reported [41,48-53].

\section{Prothrombotic Risk Factors in Paediatric Throboembolism}

Underlying triggering factors and genetic prothrombotic conditions mentioned above, as well as acquired antiphospholipid antibodies play a potential role in the paediatric population with symptomatic venous thrombosis [53, 54], or ischaemic cerebrovascular accidents $[27,44]$. Suitable data are available from case series [55-65], and case-control studies in Caucasian paediatric patients suffering from venous thrombosis $[43,56]$ or ischaemic stroke $[27,35,61,64]$ with respect to prothrombotic risk factors (Level II).

\section{Screening Tests, Time Point of Testing, and Interpretation of Laboratory Results}

Besides a step-wise protein-based diagnostic procedure the corresponding antigen concentration is not reduced when the activity of a protein is within its normal range DNA based assays are recommended. Suitable proteinbased assays, i.e. APC-resistance [66,67], protein C activity, free and total protein $\mathrm{S}$ antigen, antithrombin activity, fibrinogen concentration, plasminogen activity, coagulation factors VIIIC and XII, lipoprotein (a) [68,69], and fasting homocysteine concentrations should be investigated along with DNA-based assays, i.e. factor V G1691A mutation, prothrombin G20210A variant and MTHFR C677T genotype.

Commercially available lipoprotein (a) assays are not yet standardised. However, a working group supported by the National Institutes of Health/National Heart, Lung and Blood Institute has previously evaluated [22] lipoprotein (a) assays using reference material developed by the International Federation of Clinical Chemistry and Laboratory Medicine (IFCC) and a well-defined reference assay which is based on the immunodetection of non-repetitive epitopes within $\mathrm{Lp}(\mathrm{a})$ [68]. Overall in this trial reported, the results of various $\mathrm{Lp}(\mathrm{a})$ assays correlated well. However, individual assays for the measurement of apolipoprotein (a) were biased by $6 \%$ to $31 \%$ towards higher or lower lipoprotein (a) values so that at a given lipoprotein (a) risk threshold some assays will overestimate and some will underestimate the thrombotic risk. Therefore, and because lipoprotein (a) serum levels are mainly determined by a genetic size polymorphism of its main protein component it is useful to include also the analysis of apo(a) phe-

Thormbembolic Disease in Neonates and Children notypes [69].

In addition, rare prothrombotic defects, e.g. dysfibrinogenemia, hypo-/or dysplasminogenemia, heparin cofactor II deficiency, increased levels of histidine-rich glycoprotein, 2 macroglobulin, 1-antitrypsin, protein $\mathrm{z}$, low tissue factor pathway inhibitor concentrations or further genetic polymorphisms, should be kept in mind. Besides testing for prothrombotic defects as stated above, all symptomatic children with thrombosis should be screened for antiphospholipid or anticardiolipin antibodies and the presence of lupus anticoagulants [53,54].

To identify prothrombotic risk factors and conditions responsible for vascular accidents in children a laboratory investigation is indicated. Based on the data obtained from case-control studies (Level I: [7,18,19,36]; Level II: $[27,34,35,43,47,56,61])$, at least the symptomatic propositus should be screened in a specialised coagulation unit for prothrombotic defects. In addition, since a recent prospective study on recurrent vascular occlusion after a first episode of spontaneous venous thromboembolism, i.e. thrombosis in the absence of further secondary causes, has indicated a subgroup of paediatric patients suffering from combined prothrombotic risk factors, to be at high risk of recurrent thrombosis a search for multiple risk factors is justified in selected patient groups [36].

With respect to the Mendelian theory of inheritance, approximately $50 \%$ of siblings of a symptomatic propositus suffering from a combined prothrombotic defect carry one single risk factor, while $25 \%$ carry two or more gene mutations/polymorphisms. Thus, based on the fact that an effective prophylactic anticoagulant therapy is available in risk situations, a screening for prothrombotic risk factors has to be discussed also in non-symptomatic siblings and further first degree family members [71].

To prevent results of protein-based assays from being affected by the acute thrombotic onset plasma samples should be obtained at least 3 to 6 months after the thrombotic episode. In addition, also the use of oral anticoagulant medication influence protein-based assays. Therefore it is recommended to draw fresh plasma samples for coagulation analyses at least 14-30 days after withdrawal of oral anticoagulation. In contrast, since DNA-based assays are influenced neither by the acute thrombotic onset nor anticoagulation and thrombolytic therapy, screening can be performed for genetic mutations/polymorphisms immediately at the onset of the vascular accident. Since $\mathrm{Lp}(\mathrm{a})$ levels are increasing during the first year of life [72], reaching twofold values compared with birth values at the age of approximately one year repeated testing after 8 to 12 months following the acute thrombotic onset is mandatory, when including $\mathrm{Lp}(\mathrm{a})$ in the screening programme in Caucasian neonates suffering from thromboembolism. A repeated test-

Pathophysiol Haemost Thromb 2003/2004;33:269-274 
Table 3. Recommended screening and re-screening for prothrombotic risk factors in Caucasian neonates and children: Protein- and DNA-based methods (may vary within different ethnic backgrounds).

APC-R (APC-resistance)

Protein C-activity

Free protein S-antigen

Antithrombin-activity

Fibrinogen

Plasminogen

Factor VIIIC, factor XII

Lipoprotein (a)

Fasting homocysteine concentration

Antiphospholipid /anticardiolipin IgM/IgG
Factor V G1691A

Factor II G20210A

MTHFR C677T

Further prothrombotic polymorphisms
Protein C-activity

Free protein S-antigen

Antithrombin-activity

Fibrinogen

Plasminogen

Factor VIIIC, factor XII

Lipoprotein (a)

Fasting homocysteine concentration

Antiphospholipid /anticardiolipin IgM/lgG ing is also necessary in paediatric patients with increased anticardiolipin/ antiphospholipid IgM or IgG antibodies, or lupus anticoagulants.

For all plasma-based assays a clotting abnormality should be documented as a defect only if the plasma level of a protein is outside the limits of its normal range [55,73,74]. Besides classification based on age-dependent normal reference ranges and confirmation of a suspected protein-based prothrombotic defect in a second plasma sample (3 to 6 months later; without oral anticoagulation), criteria for the hereditary nature of a haemostatic risk factor is the identification of a causative gene mutation [32,33].

A type I deficiency state can be diagnosed when the functional plasma activity and immunological antigen concentration of a protein is below the age-related limit. A type II deficiency is present when repeatedly low functional activity levels are combined with normal antigen concentrations. As in adults, the diagnosis of protein S-deficiency is based on reduced free protein $\mathrm{S}$ antigen levels combined with decreased or normal total protein $\mathrm{S}$ antigen concentrations.

\section{Final Conclusions}

The distribution of prothrombotic risk factors vary in different countries with respect to the ethnic population background and the number of patient/controls investigated
[75-78]. Thus, to estimate the individual patient risk in paediatric patients suffering thromboembolism, it is recommended that symptomatic patient groups should be investigated in comparison with age- and gender-matched healthy controls from the same geographic catchment areas. Based on these data a step-wise screening of common and rare prothrombotic risk factors is recommended.

Since there are little data available so far with respect to the presence of inherited prothrombotic risk factors in paediatric populations others than Jews $[39,64]$ or Caucasian, $[7,19,34,36,43,47,56,61]$ the following recommendations (Level I: [7,18,19,36]; Level II: [27,34,35,43,47,56,61]) are restricted to Caucasian German and Austrian children with venous thrombosis or stroke.[7,19,34,36,43,47,56,61] In the latter cohort a screening of inherited prothrombotic risk factors listed in Table 3, including the measurement of $\mathrm{Lp}(\mathrm{a})$ concentrations is recommended along with the evaluation of underlying clinical conditions (Table 1).

\section{Acknowledgments}

The authors thank Susan Griesbach for help in editing this manuscript.

\section{References}

Andrew M. Developmental hemostasis: Relevance to thromboembolic complications in pediatric patients. Thromb Haemost 1995; 74: 415-425.

$\checkmark 2$ Andrew M, David M, Adams M, et al. Venous thromboembolic complications (VTE) in children: first analyses of the Canadian registry of VTE. Blood 1994; 83: 1251-1257.

3 Schmidt B, Andrew M. Neonatal thrombosis: report of a prospective Canadian and international registry. Pediatrics 1995; 96: 939-943.
4 Nowak-Göttl U, von Kries R, Göbel U. Neonatal symptomatic thromboembolism in Germany: two year survey. Arch Dis Child Fetal Neonatal Ed 1997; 76: F163-167.

Massicotte MP, Dix D, Monagle P, Adams M, Andrew M. Central venous catheter related thrombosis in children: Analysis of the Canadian Registry of venous thromboembolic complications. J Pediatr 1998; 133: 770-776.

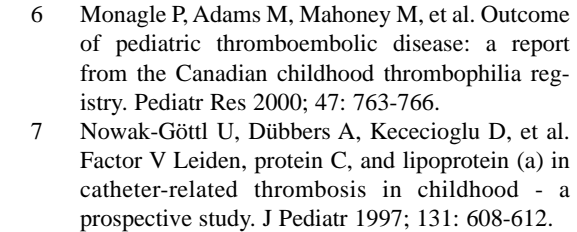

Nowak-Gött/Duering/Kempf-Bielack/Sträter 
8 Vitiello R, McCrindle BW, Nykanen D, Freedom RM, Benson LN. Complications associated with pediatric cardiac catheterization. J Am Coll Cardiol 1998; 32: 1433-1440.

$\checkmark$ Salonvaara M, Riikonen P, Kekomaki R, Heinonen K. Clinically symptomatic central venous catheter-related deep venous thrombosis in newborns. Acta Paediatr 1999;88:642-646.

10 Boo NY, Wong NC, Zulkifli SS, Lye MS. Risk factors associated with umbilical vascular catheterassociated thrombosis in newborn infants. J Pediatr Child Health 1999;35:460-465.

11 Uttenreuther-Fischer MM, Vetter B, Hellmann C, et al. Paediatric thrombo-embolism: the influence of non-genetic factors and the role of activated protein $\mathrm{C}$ resistance and protein $\mathrm{C}$ deficiency. Eur J Pediatr 1997;156:277-281.

12 Seixas CA, Hessel G, Ribeiro CC, Arruda VR, Annichino-Bizzacchi JM. Factor V Leiden is not common in children with portal vein thrombosis. Thromb Haemost 1997;77:258-261.

13 Schwartz DS, Gettner PA, Konstantino MM, et al. Umbilical venous catheterization and the risk of portal vein thrombosis. J Pediatr 1997;131:760762.

14 Grandas OH, Klar M, Goldman MH, Filston HC. Deep venous thrombosis in the pediatric trauma population: an unusual event: report of three cases. Am Surg 2000;66:273-276.

15 Kaplan DM, Fliss DM, Peiser Y, Greenberg D, Leiberman A. Internal jugular vein thrombosis in a child due to a "pencil point injury" of the palate. Int J Pediatr Otorhinolaryngol 1998;44:183-187.

$\checkmark 16$ Eire PF, Vallejo D, Sastre JL, Villaamil R, Rodriguez MA, Garrido M. An unusual complication of appendicitis in childhood. Eur J Pediatr Surg 1999;9:351-352.

17 Sifontes MT, Nuss R, Hunger SP, Wilimas J, Jacobson LJ, Manco-Johnson MJ. The factor V Leiden mutation in children with cancer and thrombosis. Br J Haematol 1997;96:484-489.

18 Mitchell L, Hoogendoorn H, Giles AR, Vegh P, Andrew $M$. Increased endogenous thrombin generation in children with acute lymphoblastic leukemia: risk of thrombotic complications in LAsparaginase-induced antithrombin III deficiency. Blood 1994;83:386-391.

19 Nowak-Göttl U, Wermes C, Junker R, et al. Prospective evaluation of the thrombotic risk in children with acute lymphoblastic leukemia carrying the MTHFR TT677 genotype, the prothrombin G20210A variant, and further prothrombotic risk factors. Blood 1999;93:1595-1599.

20 Kocak U, Gursel T, Ozturk G, Kantarci S. Thrombosis during all-trans-retinoic acid therapy in a child with acute promyelocytic leukemia and factor VQ 506 mutation. Pediatr Hematol Oncol 2000;17:177-178.

21 Schlegel N. Thromboembolic risks and complications in nephrotic children. Semin Thromb Hemost 1997;23:271-280.

22 Fabri D, Belangero VM, Annichino-Bizzachi JM, Arruda VR. Inherited risk factors for thrombophilia in children with nephrotic syndrome. Eur J Pediatr 1998;157:939-942.

23 Mocan H, Beattie TJ, Murphy AV. Renal venous thrombosis in infancy: long-term follow-up. Pediatr Nephrol 1991;5:45-49.

24 Bökenkamp A, von Kries R, Nowak-Göttl U, Göbel U, Hoyer PF. Neonatal renal venous thrombosis in Germany between 1992 and 1994: epidemiology, treatment and outcome. Eur J Pediatr 2000;159:44-48.
25 Oh J, Schäfer F, Veldmann A, et al. Heterozygous prothrombin gene mutation: a new risk factor for early renal allograft thrombosis. Transplantation 1999;68:575 - 578.

26 Heidenreich S, Dercken C, August C, Koch HG, Nowak-Göttl U. High rate of acute rejections in renal allograft recipients with thrombophilic risk factors. J Am Soc Nephrol 1998;9:1309-1313.

27 Sträter R, Vielhaber H, Kassenböhmer R, von Kries R, Göbel U, Nowak-Göttl U. Genetic risk factors of thrombophilia in ischaemic childhood stroke of cardiac origin. A prospective ESPED survey. Eur J Pediatr 1999;158;S122-125.

28 Worth LL, Hoots WK. Development of a subdural vein thrombosis following aggressive factor VI replacement for postnatal intracranial haemorrhage in a homozygous factor VII-deficient infant. Haemophilia 1998;4:757-761.

29 Escuriola Ettingshausen C, Martinez Saguer I, Kreuz W. Portal vein thrombosis in a patient with severe haemophilia A and F V G1691A mutation during continuous infusion of F VIII after intramural jejunal bleeding - successful thrombolysis under heparin therapy. Eur J Pediatr 1999;158: S180-182.

30 Escuriola Ettingshausen C, Halimeh S, Kurnik K, et al. Symptomatic onset of severe hemophilia A in childhood is dependent on the presence of prothrombotic risk factors. Thromb Haemost 2001; 85:218-220.

31 Ranze O, Ranze P, Magnani HM, Greinacher A. Heparin-induced thrombocytopenia in paediatric patients. A review of the literature ana a new case treated with danaparoid sodium. Eur J Pediatr 1999;158:S130-133.

32 Lane A, Grant PJ. Role of hemostatic gene polymorphisms in venous and arterial thrombotic disease. Blood 2000;95:1517-1526.

33 Seligsohn U, Lubetsky A. Genetic susceptibility to venous thrombosis. N Engl J Med 2001; 344 1222-1231.

34 Nowak-Göttl U, Junker R, Hartmeier M, et al Increased lipoprotein (a) is an important risk factor for venous thromboembolism in childhood. Circulation 1999;100:743-748.

35 Nowak-Göttl U, Sträter R, Heinecke A, et al. Lipoprotein (a) and genetic polymorphisms of clotting factor V, prothrombin and methylenetetrahydrofolate reductase are risk factors of ischaemic stroke in childhood. Blood 1999;94: 3678-3682.

36 Nowak-Göttl U, Junker R, Kreuz W, et al. Risk of recurrent thrombosis in children with combined prothrombotic risk factors. Blood 2001;97:858862.

37 Depka von M, Nowak-Göttl U, Eisert R, et al. Increased lipoprotein (a) levels as an independen risk factor for venous thromboembolism. Blood 2000;96:3364-3368.

38 Seligsohn U, Zivelin A. Thrombophilia as a multigenetic disorder. Thromb Haemost 1997;78:297301.

39 Salomon O, Steinberg DM, Zivelin A, et al. Single and combined prothrombotic factors in patients with idiopathic venous thromboembolism Prevalence and risk assessment. Arterioscler Thromb Vasc Biol 1999;19:511-518.

40 Formstone CJ, Hallam PJ, Tuddenham EG, et al. Severe perinatal thrombosis in double and triple heterozygous offspring of a family segregating two independent protein S mutations and a protein C mutation. Blood 1996;87:3731-3737.
41 Brenner B, Zivelin A, Lanir N, Greengard JS, Griffin JH, Seligsohn U. Venous thromboembolism associated with double heterozygosity for R506Q mutation of factor V and for T298M mutation of protein $\mathrm{C}$ in a large family of a previously described homozygous protein $\mathrm{C}$ deficient newborn with massive thrombosis. Blood 1996;88: 877-880.

42 Debus O, Koch HG, Kurlemann G, et al. Factor V Leiden and genetic defects of thrombophilia in childhood porencephaly. Arch Dis Child Fetal Neonatal Ed 1998;78:F121-124.

43 Günther G, Junker R, Sträter R, et al. Symptomatic ischemic stroke in full-term neonates: Role of acquired and genetic prothrombotic risk factors. Stroke 2000;31: 2437-2441.

44 DeVeber G, Monagle P, Chan A, et al. Prothrombotic disorders in infants and children with cerebral thromboembolism. Arch Neurol 1998:55:1539-1543.

45 Heller C, Heinecke A, Junker R, et al. Cerebral venous thrombosis in children. A multifactorial origin. Circulation 2003;1362-1367.

46 Hagstrom JN, Walter J, Bluebond-Langner R, Amatniek JC, Manno CS, High KA. Prevalence of the factor $\mathrm{V}$ Leiden mutation in children and neonates with thromboembolic disease. J Pediatr 1998;133:777-781.

47 Heller C, Schobess R, Kurnik K, et al. Abdominal venous thrombosis in neonates and infants: Role of prothrombotic risk factors - a multicentre casecontrol study. Br J Haematol 2000; 111: 534-539.

48 Seligsohn U, Berger A, Abend $\mathrm{M}$, et al. Homozygous protein $\mathrm{C}$ deficiency manifested by massive venous thrombosis in the newborn. $\mathrm{N}$ Engl j Med 1984; 310: 559-562

49 Marciniak E, Wilson HD, Marlar RA. Neonatal purpura fulminans: a genetic disorder related to the absence of protein C in blood. Blood 1985; 65: 15-20.

50 Marlar RA, Mongomery RR, Broekmans AW. Diagnosis and treatment of homozygous protein C-deficiency. Report of the Working Party on Homozygous Protein C Deficiency of the Subcommittee on Protein C and Protein S. International Committee on Thrombosis and Haemostasis. J Pediatr 1989;114:528-534.

51 Mahasandana C, Suvatte V, Marlar RA, MancoJohnson MJ, Jacobson LJ, Hathaway WE. Neonatal purpura fulminans associated with homozygous protein S deficiency. Lancet 1990; 335:61-62.

52 Pipe SW, Schmaier AH, Nichols WC, et al. Neonatal purpura fulminans in association with factor V R506Q mutation. J Pediatr 1996;128: 706-709.

53 Manco-Johnson MJ, Nuss R, Key N, et al. Lupus anticoagulant and protein $\mathrm{S}$ deficiency in children with postvaricella purpura fulminans or thrombosis. J Pediatr 1996;128:319-323.

54 Male C, Mitchell L, Julian J, et al. Acquired activated protein $C$ resistance is associated with lupus anticoagulants and thrombotic events in paediatric patients with systemic lupus erythematosus. Blood 2001;97:844-849.

55 Ehrenforth S, Junker R, Koch HG, et al. Multicentre evaluation of combined prothrombotic defects with thrombophilia in childhood. Eur J Pediatr 1999;158:S97-104. 
56 Junker R, Koch HG, Auberger K, Münchow N Ehrenforth S, Nowak-Göttl U. Prothrombin G20210A gene mutation and further prothrombotic risk factors in childhood thrombophilia. Arterioscler Thromb Vasc Biol 1999;19:25682572

57 Bonduel M, Hepner M, Sciuccati G, Torres AF, Pieroni G, Frontroth JP. Prothrombotic abnormalities in children with venous thromboembolism. Pediatr Hematol Oncol 2000;22:66-72.

58 Becker S, Heller C, Gropp F, Scharrer I, Kreuz W. Thrombophilic disorders in children with cerebral infarction. Lancet 1998;352:1756-1757.

59 Ganesan V, Kelsey H, Cookson J, Osborn A, Kirkham FJ. Activated protein C resistance in childhood stroke. Lancet 1996; 347: 260.

60 Riikonen RS, Vahtera EM, Kekomäki RM Physiological anticoagulants and activated protein C resistance in childhood stroke. Acta Paediatr 1996;85:242-244

61 Zenz W, Bodo Z, Plotho J, et al. Factor V Leiden and prothrombin gene G20210A variant in children with ischaemic stroke. Thromb Haemost 1998;80:763-766.

62 McColl MD, Chalmers EA, Thomas A, et al. Factor V Leiden, prothrombin 20210GA and the MTHFR C677T mutations in childhood stroke. Thromb Haemost 1999;81:690-694.

63 Van Beynum IM, Smeitink JA, den Heijer M, te Poele Pothoff MT, Blom HJ. Hyperhomocysteinemia: a risk for ischemic stroke in children. Circulation 1999;99:2070-2072.

64 Kenet G, Sadetzki S, Murad H, et al. Factor V Leiden and antiphospholipid antibodies are significant risk factors for ischemic stroke in children. Stroke 2000;31:1283-1288
65 Heller C, Becker S, Scharrer I, Kreuz W. Prothrombotic risk factors in childhood stroke and venous thrombosis. Eur J Pediatr 1999;158:S117121.

66 Nowak-Göttl U, Kohlhase B, Vielhaber H, Aschka I, Schneppenheim R, Jürgens H. APC-resistance in neonates and infants: Adjustment of an aPTTbased method. Thromb Res 1996;81:665-670.

67 Sifontes MT, Nuss R, Hunger SP, Jacobson LJ, Waters J, Manco-Johnson MJ. Correlation between the functional assay for activated protein $\mathrm{C}$ resistance and factor $\mathrm{V}$ Leiden in the neonate. Pediatr Res 1997;42:776-778.

68 Marcovina SM, Albers JJ, Scanu AM, et al. Use of a reference material proposed by the International Federation of Clinical Chemistry and Laboratory Medicine to evaluate analytical methods for the determination of plasma lipoprotein(a). Clin Chem 2000;46:1956-1967.

69 Marcovina SM, Hobbs HH, Albers JJ. Relation between number of apolipoprotein (a) kringle 4 repeats and mobility of isoforms in agarose gel: basis for a standardized isoform nomenclature. Clin Chem 1996;42:436-439.

70 Williams E. Disseminated intravascular coagulation. Loscalzo J, Schafer AI, eds. Thrombosis and Hemorrhage. 2nd ed. Baltimore, Philadelphia, London, Paris, Bankok, Buenos Aires, Hong Kong, Munich, Sydney, Tokyo, Wroclaw: Williams \& Willkins 1998:963-985.

71 Kosch A, Junker R, Kurnik K, et al. Prothrombotic risk factors in children with spontaneous venous thrombosis and their asymptomatic parents: a family study. Thromb Res 2000;99:531-537.
72 Wang XL, Wilcken DEL, Dudman NPB. Early expression of the apolipoprotein (a) gene: relationships between infants`and their parents` serum apolipoprotein (a) levels. Pediatrics 1992;89:401406.

73 Andrew M, Vegh P, Johnston M, Bowker J, Ofosu F, Mitchell L. Maturation of the hemostatic system during childhood. Blood 1992; 80: 1998-2005.

74 Andrew M. The relevance of developmental hemostasis to hemorrhagic disorders of newborns. Sem Perinatol 1997;21:70-85.

75 Rees DC. The population genetics of factor $\mathrm{V}$ Leiden (Arg 506 Gln). Review. Br J Haematol 1996;95:579-586

76 Zivelin A, Rosenberg N, Faier S, et al. A single genetic origin for the common prothrombotic G20210A polymorphism in the prothrombin gene. Blood 1998;92:1119-1124.

77 Conroy JM, Trivedi G, Sovd T, Caggana M. The allele frequency of mutations in four genes that confer enhanced susceptibility to venous thromboembolism in an unselected group of New York state newborns. Thromb Res 2000;99:317-324.

78 Helmhold M, Bigge J, Muche R, et al. Contribution of the apo(a) phenotype to plasma Lp(a) concentrations shows considerable ethnic variation. J Lipid Res 1991;32:1919-1928.

79 Kosch A, Koch HG, Heinecke A, Kurnik K, Heller C, Nowak-Göttl U; Childhood Thrombophilia Study Group. Increased fasting total homocysteine plasma levels as a risk factor for thromboembolism in children. Thromb Haemost. 2004;91:308-314. 